Portland State University

PDXScholar

\title{
Legal Financial Obligations \& Rehabilitation: How the Ability to Pay Fines And Fees Disproportionately Affects Citizens Based on Socioeconomic Status
}

Bailey R. Code

Portland State University

Follow this and additional works at: https://pdxscholar.library.pdx.edu/honorstheses

Part of the Criminology and Criminal Justice Commons, and the Economics Commons Let us know how access to this document benefits you.

\section{Recommended Citation}

Code, Bailey R., "Legal Financial Obligations \& Rehabilitation: How the Ability to Pay Fines And Fees Disproportionately Affects Citizens Based on Socioeconomic Status" (2021). University Honors Theses. Paper 966.

https://doi.org/10.15760/honors.990

This Thesis is brought to you for free and open access. It has been accepted for inclusion in University Honors Theses by an authorized administrator of PDXScholar. Please contact us if we can make this document more accessible: pdxscholar@pdx.edu. 
Legal Financial Obligations \& Rehabilitation: How the Ability to Pay Fines And Fees Disproportionately Affects Citizens Based on Socioeconomic Status

\author{
Bailey Code \\ School of Business, Portland State University \\ University Honors Thesis
}

February $26^{\text {th }}, 2020$ 


\section{Introduction}

In the United States, legal financial obligations (LFOs), also known as monetary sanctions or criminal justice financial obligations, refer to the fines and fees that result from an individual's involvement in the criminal justice system. LFOs primarily consist of fines, property forfeiture, costs, and fees. The intended benefits of these monetary sanctions include deterring crime, making restitution to victims, and encouraging appearance in court (Liu, 2019).

These types of monetary penalties began in Europe during the middle ages and were eventually adopted by the United States (Green, 2018). Today, these fines and fees have become the customary form of punishment used by the legal system in this country. Legal financial obligations are harmful to those entangled within the justice system, as shown by their cyclical nature and lack of regulated implementation. Furthermore, these monetary sanctions have been proven unnecessary due to the costs of collection often exceeding the revenues received from offenders and through the comparative effectiveness of rehabilitation programs.

There have been many discussions regarding the need for criminal justice reform in the United States, primarily focused on the dramatic growth of the country's incarcerated population; the number of Americans behind bars is now over 2.2 million, with more prisoners than any other developed nation ("Fines, Fees, and Bail," 2015). Similarly, concerns are rising in regard to the expanding use of monetary penalties, which have been shown to disproportionately impact poor defendants and offenders. Additionally, there are many private corporations profiting off of this system with little to no supervision from the government (Albin-Lackey, 2018).

One of the main factors that cause these fines and fees to disproportionately impact poor offenders is largely due to their cyclical nature. In the United States, LFOs were adopted with the intention of creating a system in which offenders are responsible for their own court costs. In the 
1990's, policy makers began to argue that taxpayers should not bear the responsibility for the increasing costs of the criminal justice system ("Fines, Fees, and Bail," 2015). These arguments stood on the premise that crime does significant harm to the victim as well as the community in regard to resources that must be allocated towards law enforcement, restitution, sentencing, and supervision.

However, legal debt for the citizens attempting to reintegrate into society has the tendency to be damaging and counterintuitive; this type of debt not only limits their income from garnished wages, but also affects their credit rating and impedes one's ability to find housing. There is a clear correlation between poverty and crime and many offenders are unable to pay their LFOs, which often results in further incarceration. In this way, the use of these fines and fees tends to increase tax spending, counterintuitive of their original purpose. Likewise, the common use of LFOs such as fixed bail bonds as conditional for pretrial release has resulted in a system where freedom is based on one's socioeconomic position rather than the seriousness of one's offense. Therefore, I will be using a combination of peer-reviewed articles, conflicting opinions, statistics, and government documents in order to shed light on the cyclical nature of legal financial obligations and the importance of rehabilitation throughout this paper.

\section{The Importance of Rehabilitation}

In the criminal justice system, many consider rehabilitation as the ultimate goal of incarceration, assuming that those convicted can be treated and desist from crime in the future. The concept of rehabilitation in the penal system has been present in this country for centuries; for example, the Colorado State Penitentiary introduced a night school available for inmates with good behavior in 1882 (Colorado College, 2016).

From the late 1950's through the 1960's, rehabilitation was the main focus of prison policy in the United States (Benson, 2003). A community health movement placed emphasis on 
the treatment of mental illness, which led to an influx of programs that would allow for easier reintegration for convicts after their time has been served. This was an important step for rehabilitation, as the U.S. Department of Justice has estimated that $15-20 \%$ of prisoners are mentally ill (Benson, 2003; Fuller \& Zdanowicz, 2014). During that time, mandated treatment for such issues was a routine aspect of sentencing, which ultimately resulted in a lower prison population.

Since Nixon's presidential administration began in the early 1970's, however, rehabilitation has become a lower priority in the U.S. justice system, replaced by a thought process that emphasizes punishment. In turn, this has decreased the amount of services formerly provided such as occupational training and health services, resulting in far higher incarceration rates. Though the United States is home to only 5 percent of the world's population, this country incarcerates 25 percent of the world's prisoners (Laguna, 2020).

Currently, more than half of prisoners are re- incarcerated within three years of their initial release. According to the National Institute of Justice, if effective rehabilitation programs are implemented, we could expect to see a reduction in recidivism rates by $20 \%$ (Petersilia, 2011). Research has also shown that prisoners that receive a high school equivalency diploma and have access to vocational skills training are more likely to get jobs after release ("Fines, Fees, and Bail,” 2015).

\section{Legal Financial Obligations}

The most commonly utilized LFOs are fines, fees, probation, and bail. These types of collections are primarily intended to subsidize the costs of criminal justice proceedings and may also be used to compensate victims for losses (Beckett, 2008).

First, fines are monetary punishments for misdemeanors or felonies, intended to deter crime, punish offenders, and compensate victims. There are also fees, which are payments for 
court activities and incarceration, charged to defendants deemed guilty of infractions, misdemeanors or felonies. In contrast to fines, fees are intended to raise revenue and often bear no relation to the offense committed (Menendez, 2019). Third is probation, which is a supervised release that is conditional of good behavior and subsidized by the offender. Lastly, bail is a form of payment for the defendant's release from jail prior to court proceedings and sentencing. Bail payments are specifically used to incentivize defendants to appear at court and, in some cases, to mitigate the risk of returning an alleged criminal to the community ("Fines, Fees, and Bail," 2015). However, bail as a monetary sanction could be construed as a contribution to a system in which an individual's freedom is centered around wealth rather than personal responsibility.

There is evidence that shows the ability to pay bail can affect the outcome of court cases. The findings from a 2018 study in the Journal of Law, Economics, \& Organization suggested that those who are unable to pay bail and go through pretrial detention are $13 \%$ more likely to be convicted, experience $42 \%$ increase in length of incarceration, and have a $41 \%$ increase in the amount of court fees owed (Stevenson, 2018). Recent data has shown that roughly a third of felony defendants are held on bail before court proceedings (“Fines, Fees, and Bail," 2015).

The implementation of LFOs is inconsistent. In the United States, drug convictions accumulate significantly larger fees and fines than offenses involving violence (Beckett, 2008). The harshness of drug- related sentencing can be attributed to the "War on Drugs" campaign that began in the early 1970's.

\section{The War On Drugs}

With a closer look at the origins of the war on drugs and the administration responsible, one can see the connection between the severity of LFOs regarding drug- related crimes. As stated by President Nixon's Domestic Policy Advisor, John Ehrlichman: 
The Nixon campaign in 1968, and the Nixon White House after that, had two enemies: the antiwar left and black people. You understand what I'm saying? We knew we couldn't make it illegal to be either against the war or black, but by getting the public to associate the hippies with marijuana and blacks with heroin, and then criminalizing both heavily, we could disrupt those communities. We could arrest their leaders, raid their homes, break up their meetings, and vilify them night after night on the evening news. Did we know we were lying about the drugs? Of course, we did. (Johnson \& Hoopes, 2018)

The implications of Ehrlichman's statement is displayed throughout policy changes during Nixon's presidency and beyond. Once the Nixon administration ended, Jimmy Carter became president in 1977 after running a campaign to decriminalize marijuana. During his first year in office, the Senate Judiciary Committee voted to decriminalize up to one ounce of marijuana, but most war on drugs policies previously established remained largely untouched during his time in office (History.com Editors, 2017).

In the 1980's, Ronald Reagan's administration further extended the war on drugs policies that had gone largely untouched during Jimmy Carter's presidency. During that time, Carter has been quoted as saying "We're taking down the surrender flag that has flown over so many drug efforts. We're running up the battle flag (Landmark Recovery, 2021)." As promised, one of the most consequential pieces of legislation throughout the war on drugs was established during Reagan's presidency: the Anti- Drug Abuse Act of 1986 (Mendoza, 2010). This act provided over a billion dollars in funding towards the drug war and implemented a number of new mandatory sentences for the possession of drugs (Landmark Recovery, 2021). Many believe this policy change greatly contributed to the dramatic increase in the incarcerated population; the number of citizens behind bars for nonviolent drug offenses rose from 50,000 in 1980 to more 
than 400,000 in 1997 (Landmark Recovery, 2021). To address the disparity and waning public support of the war on drugs, Congress passed the Fair Sentencing Act in 2010, eliminating some of the mandatory minimum sentencing for drug possession (History.com Editors, 2017).

The United States has spent an estimated \$1 trillion on the war on drugs since 1971. Despite this, many have spoken out about the campaign's ineffectiveness, including Gil Kerlikowske, a former Commissioner of U.S. Customs and Border Protection, "In the grand scheme, it has not been successful. Forty years later, the concern about drugs and drug problems is, if anything, magnified, intensified (Mendoza, 2010)." Furthermore, the federal government spent an estimated \$9.2 million every day to incarcerate those with drug related offenses in 2015 (Pearl, 2018). From 1985 to 2000, drug related arrests accounted for two thirds of the rise in the federal inmate population (Johnson \& Hoopes, 2018). In a 2014 poll, Pew discovered that 67\% of Americans would prefer the government provide treatment for illegal drug addiction rather than prosecute and incarcerate (Laguna, 2020). In this sense, the war on drugs has proven to be a significant cost to both the United States government and its citizens. The war on drugs has had a lasting effect on policy despite the fact that the majority of states have softened their drug laws and minimum sentences for possession. Today, there are nearly 450,000 incarcerated in the U.S. on drug related charges alone (Wagner, 2020).

\section{The Cyclical Nature of LFOs}

Legal financial obligations are considered by many to be a critical barrier in the rehabilitation process. In interviews conducted by The Washington State Minority and Justice Commission, half of those surveyed with criminal convictions had incomes that fell below the federal poverty line (Beckett, 2008). Many of those interviewed had dependents they were financially supporting, and would fall behind on their LFOs, which would cause them to rise due 
to accrued interest (Beckett, 2008). Many of those surveyed disclosed that the threat of lost wages disincentivizes them to work, increasing the probability that they will re- offend (Beckett, 2008).

Even without monetary sanctions, it is difficult for the formerly incarcerated to find housing and employment after serving their sentences. Still, many jurisdictions in the United States determine the assigned LFOs based on the crime committed rather than the defendant's ability to pay. Therefore, monetary sanctions such as bail are often set at a high rate relative to what the defendant can afford to pay; according to the Brookings Institution, the median bail amount is more than $\$ 10,000$ for felony defendants (Liu, 2019). As shown below, most people in prison are of low socioeconomic status pre- incarceration:

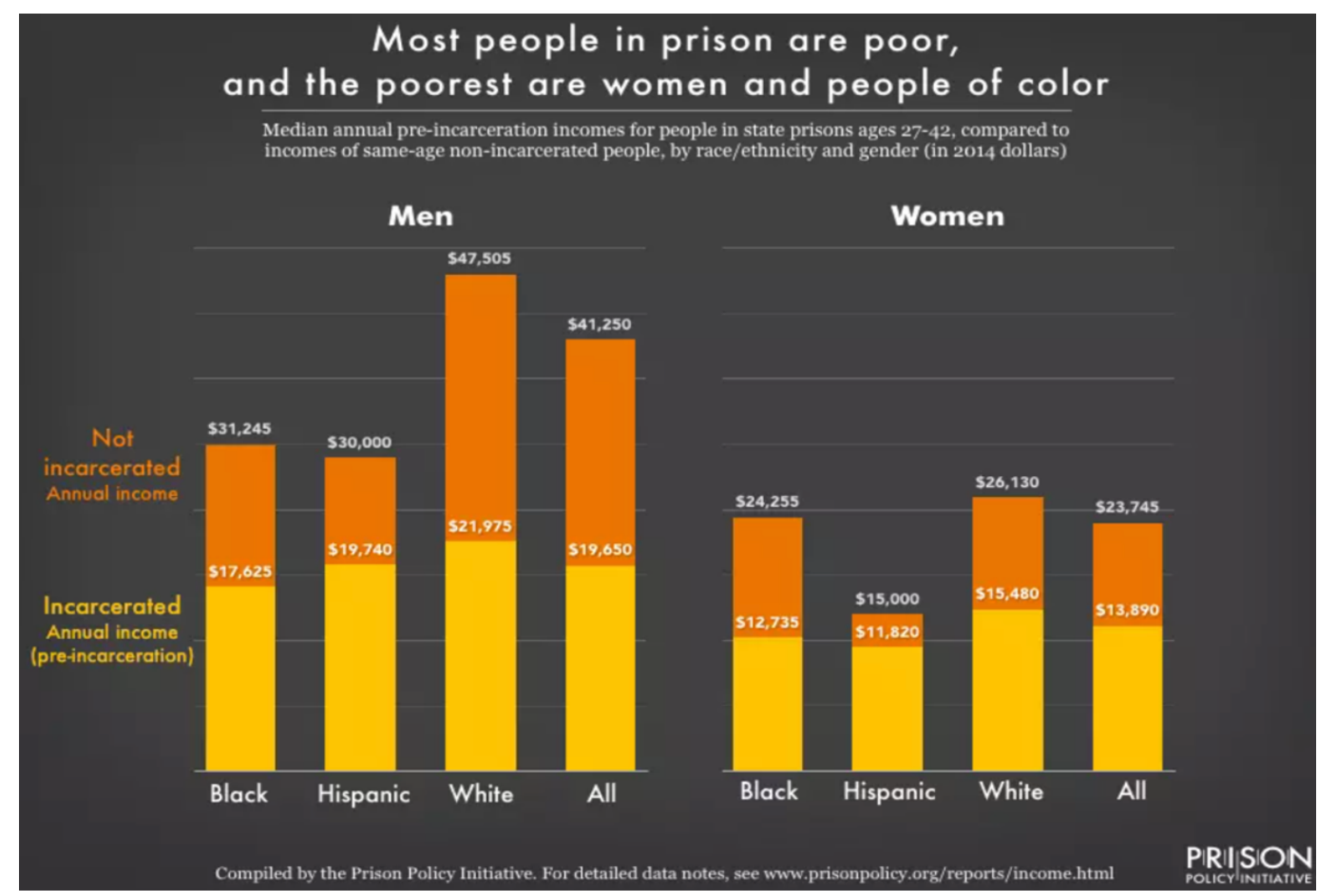


The long- term nature of legal debt prevents many people with LFOs from applying to have their criminal records sealed, which only exacerbates their existing economic disadvantages (Beckett, 2008). Some stop paying their debt altogether, resulting in a warrant for their arrest. According to the Washington State Minority and Justice Commission, "Persons with warrants stemming from violation of a felony sentence are considered "fleeing felons", and thus are ineligible for federal benefits including Temporary Assistance for Needy Families, Social Security Insurance (SSI), public or federally assisted housing, and food stamps (Beckett, 2008)." In some jurisdictions in the United States, roughly $20 \%$ of all jail inmates were incarcerated due to failure to pay their LFOs ("Fines, Fees, and Bail," 2015). The practice of imprisoning those who are unable to pay creates incentive for previous offenders to become fugitives and hide from authorities, making it more difficult for them to disconnect from the criminal justice system.

Furthermore, fixed payments for a given offense create "penalties more punitive for poorer individuals than for wealthier individuals (Albin- Lackey, 2018)." Having the ability to pay yields better representation, pre- trial freedom, and an opportunity for diversion programs rather than "ordinary prosecution ("Fines, Fees, and Bail," 2015)."

In certain situations, there is an option for a "pay only" type of probation, in which one can skip probation altogether and disentangle themselves from the legal system if they have the funds to pay their monetary sanctions up front (“Fines, Fees, and Bail," 2015). In many jurisdictions, if one cannot pay their debt immediately, they have to be supervised by a private probation company, which adds a "supervision fee" to their existing LFOs. Therefore, those who are financially unstable end up paying significantly more in the long run (Albin- Lackey, 2018). To demonstrate the issue visually, the graph below shows the average progression of these charges with an initial fine of $\$ 2,000$. 
This graph shows the direct

correlation between lower monthly payments with a much higher total amount owed. At the extreme end of this spectrum, offenders would benefit more from getting a loan to pay off their debt, even with the highest interest rates. With a loan, they could pay off their criminal justice debt immediately, decrease their length of probation and their accompanying supervision fees, and avoid the looming threat of being jailed for missed payments.

Policy makers and probation company officials argue that the above system is beneficial to offenders because it provides a longer period to pay their fines, but it becomes more damaging in the long run. In this sense, many local courts have repurposed the concept of probation into merely a debt collection tool rather than to serve its original purpose- a means to rehabilitate those involved in the justice system and ensure a re-offense does not occur.

The obstacles that alleged offenders face can be exacerbated if they choose to fight their case and lose. For example, in Montgomery, Alabama, residents are fined \$20 for violating the city's noise ordinance. If the person fined chose to contest the citation, they would be faced with a \$257 charge if they are found guilty (Albin-Lackey, 2018). In Georgia, misdemeanor offenses result in "state- mandated surcharges" in addition to the existing court costs (Albin-Lackey, 2018). According to the Washington State Minority and Justice Commission, convictions that result from a trial rather than a guilty plea tend to yield higher penalties (Beckett, 2008). 
A major issue regarding LFOs is their inconsistencies on a federal level- in the United States, these types of charges can vary significantly from county to county. For instance, monetary sanctions have been shown to be utilized more in cities with a larger African American population, and according to The Brookings Institution, "cities in the highest quintile of black share of population collect roughly $\$ 29$ in criminal justice revenues per resident, whereas cities in the lowest quintile collect only $\$ 9$ (Liu, 2019)." For instance, after an investigation on the Ferguson Police Department in Missouri, The Department of Justice revealed that the town "set revenue targets for criminal justice fines and fees of over $\$ 3$ million in 2015, covering over $20 \%$ of the town's operating budget ("Fines, Fees, and Bail," 2015)."

Furthermore, an assessment and analysis of court records in Washington state showed that defendant, case and county characteristics impact the implementation of LFOs in individual cases, even after the seriousness of the offense is taken into account (Beckett, 2008). After controlling for legal factors, the analysis found that Hispanic defendants were more likely to accrue higher LFOs than white defendants. Men were more likely to be given higher fines than women (Beckett, 2008).

The implementation of LFOs has significantly increased throughout the last 40 or so years, primarily motivated by budgetary considerations. These criminal justice expenditures have been shown to not only impact offenders, but budget pressures in state and local governments as well. Monetary sanctions in themselves incur significant costs to the legal system through enforcement expenditures, which are estimated to be around $\$ 900$ per capita each year (Liu, 2019). Research has shown that jurisdictions which rely heavily on LFOs can distort police behavior and law enforcement. For example, towns with budgetary issues tend to place an emphasis on traffic violations or enforce new laws in order to generate revenue (Liu, 2019). One study in the Journal of Law and Economics showed that traffic tickets were not only used to 
ensure safety but to accommodate for budget shortfalls (Garrett \& Wagner, 2009). The data showed that a $10 \%$ budget deficit resulted in $6 \%$ more tickets issued (Garrett \& Wagner, 2009). This is largely due to the pressures faced by local governments. This can be seen through the total growth in criminal justice expenditures in the past few decades; between 1990 and 2012, the spending grew by $74 \%$ from $\$ 157$ to $\$ 273$ billion (“Fines, Fees, and Bail," 2015). On average, criminal justice expenditures represent over $7 \%$ of state general funds, and 11 states spent more in this sector than on private education in 2013 ("Fines, Fees, and Bail," 2015).

\section{Utilization of LFO Revenue}

Many localities have become reliant on revenue from criminal courts to subsidize their operations. For instance, North Carolina uses fees to fund half of the state's judicial budget as well as jails, law enforcement, and schools (Menendez, 2019). These local governments begin to expect the courts to turn a profit in the correctional system, creating the potential to distort the fair administration of justice.

Although LFOs were adopted with the intention of subsidizing criminal justice expenditures, data shows that in many cases, the cost of collection exceeds the revenues received from offenders ("Fines, Fees, and Bail," 2015). The costs of law enforcement and probation supervision is high and the collection rates are low. One example is that in the state of Washington, \$21 million worth of fee revenue was collected in 2006, but there was a net gain of roughly $\$ 6$ million ("Fines, Fees, and Bail," 2015). Additionally, the average daily cost of jailing is $\$ 50$ - $\$ 500$ per inmate, and the total annual cost of pre-trial detention in the United States is approximately \$9 million (“Fines, Fees, and Bail,” 2015).

An article from the National Institute of Corrections focuses on the often-overlooked issue of "offender- funded" probation services- when for- profit probation agencies are allowed 
to supervise the probation of offenders with little governmental oversight (Albin-Lackey, 2018). As the number of probationers in the U.S. has increased over the past decades, states have decreased their funding for probation programs and have increasingly relied on outsourcing to provide the required supervision (Dolan, 2015). Every year, the government sends hundreds of thousands of people to these private corporations that hold the offender fiscally responsible for their supervision in order to prevent the cost falling on the taxpayer. Many of these offenders are guilty of minor crimes such as misdemeanors or previous failure to pay their LFOs (AlbinLackey, 2018).

The Supreme Court has long affirmed that "debtor's prisons" are unconstitutional, but the modern version of said practices remains (Dolan, 2015). The cost of fee collection is dramatically increased when jurisdictions jail offenders for failure to pay; in Rhode Island, more than $13 \%$ of incarcerations that resulted from failure to pay LFOs in 2008 had direct incarceration costs that exceeded the outstanding debt that was owed in the first place ("Fines, Fees, and Bail," 2015). Therefore, the high cost associated with imprisoning those who cannot pay their debts is a crucial component that determines the effectiveness of LFOs.

\section{Recommendations}

The assessment of LFOs is characterized by a high degree of variability that cannot be attributed solely to the seriousness of the offense or the offender. Analyses of court records show that "counties characterized by smaller populations, higher drug arrest and violent crime rates, and/or comparatively small proportions of their budgets devoted to law and justice assess significantly higher fees and fines (Beckett, 2008)." Signs also show that defendants who have criminal records may accrue very different amounts of debt depending on where they are convicted. 
The current justice system does not allow for offenders to be effectively rehabilitated and makes reintegration into society after serving one's sentence more difficult than necessary. Outlined below are a number of recommendations to address the systemic issues that LFOs exacerbate (Bannon, 2010).

1. Lawmakers should establish an initial investigation of the debt burden on individual cases before determining the appropriate fees to assign.

2. Courts should offer community service programs with flexible scheduling as an alternative for those unable to pay their criminal justice debt.

a. In order to prevent issues such as work conflicts, there must be flexible scheduling. Ideally, these programs would also include the opportunity to develop occupational skills.

3. States should eliminate penalties for those unable to pay their debt up front, such as late fees, interest, and payment plan fees.

a. This practice is more punitive for poorer individuals and should be corrected. Fees that are collected by private agencies are particularly problematic, as they tend to lack oversight and charge higher rates.

4. Before the court has made an ability to pay determination, states should completely halt the practice of jailing individuals or revoking driver's licenses for failure to pay their criminal justice debt.

a. Additionally, policy makers should evaluate the costs of these practices and make said information readily available to the public. 


\section{Conclusion}

The increased utilization of legal financial obligations throughout the last 40 years is indicative of the larger problem- the rate of incarceration in the United States. LFOs exacerbate existing issues for all parties involved in the justice system through distorted behavior from law enforcement, waste of governmental resources, and complexifying true rehabilitation in citizens. Although many state and local governments have become reliant on monetary sanctions in the criminal justice system, reform is necessary to solve these budgetary challenges while maintaining a sense of fairness and public safety. 


\section{References}

Albin-Lackey. (2018, September 12). Profiting from Probation: America's "Offender-Funded" Probation Industry. Retrieved November 09, 2020, from https://nicic.gov/profitingprobation-america $\%$ E2\%80\%99s-\%E2\%80\%9Coffender-funded $\%$ E2\%80\%9Dprobation-industry

Bannon, A., Nagrecha, M., \& Diller, R. (2010). Criminal Justice Debt: A Barrier to Reentry. Retrieved November 07, 2020, from https://www.brennancenter.org/sites/default/files/2019-08/Report_Criminal-Justice-Debt$\% 20 \mathrm{~A}-$ Barrier-Reentry.pdf

Beckett, K., Harris, A., \& Evans, H. (2008, August). THE ASSESSMENT AND CONSEQUENCES OF LEGAL FINANCIAL OBLIGATIONS IN WASHINGTON STATE. Retrieved January 02, 2021, from https://www.courts.wa.gov/committee/pdf/2008LFO_report.pdf

Benson, E. (2003, August). Rehabilitate or punish? Retrieved November 15, 2020, from https://www.apa.org/monitor/julaug03/rehab

Colorado College. (2016, August 05). Defining rehabilitation. Retrieved March 1, 2021, from https://sites.coloradocollege.edu/hip/defining-rehabilitation/

Dolan, K. (2015). The Poor Get Prison: The Alarming Spread of the Criminalization of Poverty. Retrieved 2020, from https://ips-dc.org/wp-content/uploads/2015/03/IPS-ThePoor-Get-Prison-Final.pdf

Fines, Fees, and Bail: Payments in the Criminal Justice System That Disproportionately Impact The Poor. (2015, December). Retrieved from https://obamawhitehouse.archives.gov/sites/default/files/page/files/1215_cea_fine_fee_ba il_issue_brief.pdf

Garrett, T., Wagner, G. (2009). Red Ink in the Rearview Mirror: Local Fiscal Conditions and the Issuance of Traffic Tickets. Retrieved January 05, 2021, from https://chicagounbound.uchicago.edu/jle/vol52/iss1/4/

Fuller, T., \& Zdanowicz, M. (2014, April). The Treatment of Persons with Mental Illness in Prisons and Jails: A State Survey. Retrieved from https://www.treatmentadvocacycenter.org/storage/documents/treatment-behindbars/treatment-behind-bars.pdf

Green, E. (2018, November 18). Monetary sanctions and the vicious circle of poverty they perpetuate. Retrieved November 25, 2020, from https://www.streetroots.org/news/2018/11/16/monetary-sanctions-and-vicious-circlepoverty-they-perpetuate

History.com Editors. (2017, May 31). War on drugs. Retrieved February 20, 2021, from 
https://www.history.com/topics/crime/the-war-on-drugs

Johnson, C., \& Hoopes, J. (2018, April). The War on Drugs and the Case for Rehabilitation. Retrieved from https://scholarsarchive.byu.edu/cgi/viewcontent.cgi?article=1316\&context=byuplr

Landmark Recovery, L. (2021, February 04). The history of the war on Drugs: Reagan era and beyond. Retrieved February 13, 2021, from https://landmarkrecovery.com/history-of-thewar-on-drugs-reagan-beyond/

Laguna. (2020, January 07). Was the war on drugs effective? Retrieved February 25, 2021, from https://lagunatreatment.com/addiction-research/war-on-drugs/

Liu, P., Nunn, R., \& Shambaugh, J. (2019, April 11). Nine facts about monetary sanctions in the criminal justice system. Retrieved January 2, 2021, from https://www.brookings.edu/research/nine-facts-about-monetary-sanctions-in-thecriminal-justicesystem/\#: :text=These\%20are\%20important\%20costs\%20in,and\%20making\%20restituti on $\% 20$ to $\% 20$ victims

Mendoza, M. (2010, May 13). U.S. drug war has met none of its goals. Retrieved February 27, 2021, from https://www.nbcnews.com/id/wbna37134751

Menendez, M., Crowley, M., Eisen, L., \& Atchison, N. (2019, November). The Steep Costs of Criminal Justice Fees and Fines. Retrieved November 7, 2020, from https://www.brennancenter.org/sites/default/files/201911/2019_10_Fees\%26Fines_Final5.pdf

Pearl, B. (2018, June 27). Ending the war on Drugs: By the numbers. Retrieved February 15, 2021, from https://www.americanprogress.org/issues/criminaljustice/reports/2018/06/27/452819/ending-war-drugs-numbers/

Petersilia, J. (2011, November). Beyond the prison bubble. Retrieved February 27, 2021, from https://nij.ojp.gov/topics/articles/beyond-prisonbubble\#: :text=Rehabilitation\%20programs\%20reduce\%20recidivism\%20if,are\%20targe ted $\% 20$ to $\% 20$ specific $\% 20$ offenders.\&text $=I \mathrm{If} \% 20 \mathrm{we} \% 20$ could $\% 20 \mathrm{implement} \% 20$ effecti ve,by $\% 2015 \% 20$ to $\% 2020 \% 20$ percent.

Stevenson, M. T. (2018). Distortion of Justice: How the Inability to Pay Bail Affects Case Outcomes. Journal of Law, Economics \& Organization, 34(4), 511-542. https://doiorg.proxy.lib.pdx.edu/10.1093/jleo/ewy019

Wagner, W. (2020, March 24). Mass incarceration: The whole pie 2020. Retrieved February 10, 2021, from https://www.prisonpolicy.org/reports/pie2020.html 